\title{
„Druhý život" T. G. Masaryka v Bulharsku (1937)
}

\section{T. G. Masaryk's "Second Life" in Bulgaria (1937)}

Krasimira Marholeva / krassimarholeva@gmail.com

Katedra Obecné antropologie, Fakulta humanitních studií, Univerzita Karlova

\begin{abstract}
The aim of the current paper is to assess the Bulgarian reflections on T. G. Masaryk's death in 1937. I am going to apply the theoretical approach of the German historian Reinhart Koselleck, who asserted that the "political cult of the dead" should be explored in a certain historical context and the commemoration of the "dead hero" was intended to reconstruct historical events and images. Therefore, before approaching my main objective, I will make a brief overview of the Bulgarian image of TGM in the context of the Bulgarian-Czechoslovak political relationship during the interwar period.

I rely mainly on Bulgarian and Czechoslovak periodical press as well as on archival sources, published documents, and secondary literature, related to the subject. In my case study the periodical press assumes the role of intercultural communication and a mechanism of constructing cultural and national stereotypes.
\end{abstract}

\section{Keywords}

T. G. Masaryk, Bulgaria, Czechoslovak-Bulgarian interwar relationship, cult of the dead hero, Bulgarian periodical press 
„Masaryk nepatři pouze své vlasti, on je universálni." Slovo, 15. 9. 1937

\section{Úvod}

V roce 2020 oslavily Bulharsko a Česká republika 100 let bilaterálních diplomatických vztahů. Toto výročí lze hodnotit i jako symbolický návrat k osobnosti prvního československého prezidenta Tomáše Garrigua Masaryka, protože ten měl hlavní zásluhu na navázání diplomatických styků mezi Bulharskem a Československem v roce 1920. Tímto výročím se myšlenkově vracíme i do druhé poloviny září roku 1937, kdy český novinář Vladimír Sís (1889-1958), bratr českého politika Františka Síse (1878-1938), připomněl svým čtenářům na stránkách Národních listů, že právě jeho jednání s prvním československým prezidentem v lednu 1919 v Praze působilo jako katalyzátor navázání oficiálních vztahů mezi oběma státy. ${ }^{1}$ Svůj článek V. Sís napsal pří příležitosti úmrtí prvního československého prezidenta dne 14. září 1937. Tehdy se s T. G. Masarykem navždy rozloučilo nejen Československo, ale i celý svět. ${ }^{2}$ Během smutečných slavností v září roku 1937 Bulharsko nezůstalo za ostatními státy pozadu. Jak uvedly Pražské noviny, bulharské listy „jsou preplněny obšínými životopisy a množstvím obrázki̊ prezidenta-Osvoboditele a přinášeji hojně zpráv o zármutku v Československu od svých zvláštnich zpravodajü“.”

Nabízí se proto následující otázka: Jak byl zesnulý T. G. Masaryk hodnocen bulharskou veřejnostı? Cílem této stati je přiblížit bulharské reflexe Masarykovy smrti v roce 1937.

Podobný rituál - komemorace vynikajících postav, které dávno odešly ze života, se definuje jako „kult mrtvého hrdiny“. Takzvaný „politický kult mrtvých“ poprvé konceptualizoval německý sociální historik Reinhart Koselleck, jenž tvrdil, že připomínání těch, kdo zemřeli za svou vlast, je součástí politické kultury daného národa. Jak tvrdí R. Koselleck, navzdory tomu, že koncepce „politického kultu mrtvých“ patří do sféry antropologie, dá se zkoumat pouze v historickém kontextu. Komemorace „mrtvého hrdiny“ slouží k rekonstrukci historických událostí a obrazů, uvedl dále německý historik. ${ }^{4} \mathrm{~V}$ tomto smyslu komemorace napomáhá konstruování kolektivního obrazu minulosti.

Ke zkoumání hlavního cíle našeho výzkumu je proto nutno nejdříve načrtnout krátký historický exkurz. V následujících řádcích tedy stručně přiblížíme Masarykův obraz v meziválečném Bulharsku v kontextu československo-bulharských vztahů, jakkoli je tento problém už zkoumán současnými badateli, ${ }^{5}$ a to víceméně v souvislosti s konkrétními

1 Sís, Vladimír: T. G. Masaryk o Bulharsku, Národní listy, 19. 9. 1937, č. 257, s. 6.

2 Srov. Hájková, Dagmar: Constructing National Unity. Commemorations of Tomáš G. Masaryk’s Death. Střed 2012, č. 1, s. 33-55.

3 „Bulharsko: Masarykova památka bude věčně žit". Pražské noviny, 17. 9. 1937, č. 218, s. 1.

4 Koselleck, Reinhart: Einleitung, in: Koselleck, Reinhart - Jeismann, Michael (Hrsg.), Der Politische Totenkult. Kriegerdenkmäler in der Moderne, München 1994, s. 7.

5 Marholeva, Krasimira: Tomáš Garrigue Masaryk a Bulharsko v obdobi let 1918-1923. In: Edd. J. ŠkerlováM. Vitko: Promýšlet Evropu dvacátého století: Hybatelé dějin? Brno 2017, s. 77-100; Rychlík, Jan: T. G. Masaryk, Bulhaři a makedonská otázka. In: Doubek, Vratislav - Hladký, Ladislav - Vlček, Radomír a kol.: T. 
událostmi v meziválečném Československu ${ }^{6}$ nebo v kontextu československo-bulharských oficiálních kontaktů. ${ }^{7}$

Zanalyzovali jsme také bulharské reflexe Masarykovy smrti v bulharských politických denících a populárních časopisech. V naší stati aplikujeme chronologický přístup. Vedle archivních pramenů a knižních publikací se opíráme o československý a bulharský periodický tisk, který v tomto případě hraje roli prostředníka kulturní komunikace mezi Československem a Bulharskem a nástroje sloužícího ke konstruování kulturních a národních stereotypů. V tomto ohledu vycházíme z tezí Benedikta Andersona, že noviny jsou jedním z technických prostředků k „reprezentaci“ národa. ${ }^{8}$

\section{T. G. Masaryk a Bulharsko v kontextu česko(slovensko)-bulharských vztahů do roku 1937}

Před první světovou válkou měl Tomáš G. Masaryk mezi Bulhary vysokou prestiž, protože po druhé balkánské válce (1913) se bulharští intelektuálové a politici snažili získat jeho pomoc coby zprostředkovatele mezi Bulhary a Srby. ${ }^{9} \mathrm{~V}$ předvečer první světové války český profesor veřejně prohlásil, že nepovažuje mezistátní hranici na Balkáně za definitivní ${ }^{10}$ a podnikal kroky ke smíření obou národů či jejich reprezentací. ${ }^{11}$ Vypuknutí válečného konfliktu ale jeho pokus zmařilo.

G. Masaryk a Slované. Praha 2013; Todorov, Veličko: Bălgarskoto slučvane na Tomáš Garrigue Masaryk. In: Svetovnost, demokracija, malki narodi. Sborník materiálu ot naučna konferencija, provedena na 10. - 11. noemvri 2000 g. Sofie, 2001, s. 13-23; Dimitrov, Dimităr: Tomaš Masaryk a Dimităr Michalčev - kăm faktologijata na edno prijatelstvo, s. 111-116. In: tamtéž.

6 Marholeva, Krasimira: Obraz T. G. Masaryka v Bulharsku při př́ležitosti jeho 80. narozenin. In: Doubek, V. Hladký, L. - Vlček, R. a kol.: T. G. Masaryk a Slované, s. 375-397.

7 Vasilev, Vasil: Z bulharsko-československých diplomatických vztahů mezi dvěma světovými válkami. Slovanský přehled 56, 1970, č. 6, 424-433; Týž: Bălgaro-čehoslovaškite političeski otnošenija (1926-1931). Istoričeski přehled 1972, č. 3, s. 17-48; Kolář, Josef: Počátky československo-bulharských diplomatických vztahů v letech 1919-1923. Slovanský přehled 56, 1970, s. 418-423; Týž: Alexandr Stambolijski v Československu. Slovanský přehled 65, 1979, s. 262-270; Týž,: Československo, Jugoslávie a Cankova vláda Demokratického sgovoru. Slovanský přehled 65, 1979, s. 517-528; Týž: Pokusy o narovnáni mezi Sofii a Bělehradem v letech 1926-1928, Slovanský přehled 66, 1980, s. 111-119; Týž: Arbitrážni smlouva československo-bulharská a vztahy jugoslávsko-bulharské. Slovanský přehled 67, 1981, s. 320-328; Týž: Bulharská demokratická emigrace v Československu v letech 1923-1933. Praha 1983; Týž: Československá diplomacie a Bulharsko za vlády Národního bloku. Slovanský přehled 1986, č. 4; Týž: K hodnoceni postoje Československa k Bulharsku a Jugoslávii mezi dvěma světovými válkami. In: Práce z dějin slavistiky 17, Praha 1994, s. 155-172; Rychlík, Jan: Zahraničně-politické vztahy mezi Československem a Bulharskem (1918-1992), In: Antropologie dialogu. Souznění a nedorozumění mezi Čechy a Bulhary. Praha 2000, s. 36-47; Dobrijanov, Todor: Profesor Tomáš Masaryk i težnenijata na Bălgaria v kraja na Părvata svetovna vojna. In: Svetovnost, demokracija, malki narodi, s. 103-105.

8 Anderson, Benedict: Imagined Communities: reflection on the origin and spread of nationalism. London, Verso 1991, s. 25 .

9 Dimitrov, D. Tomaš Masaryk a Dimităr Michalčev, s. 111-112.

10 Srov.: Masaryk, Tomáš Garrigue: Rakousko a Balkán. Naše doba, říjen 1914, s. 980-984.

11 Týž: Světová revoluce. Za války a ve válce. Praha 2005, s. 13. 
Po první světové válce zůstal Masarykův postoj k Bulharsku kladný. Ve své knize Nová Evropa doporučil, aby byly uznány bulharské předválečné hranice. ${ }^{12}$ Bulharská společnost a bulharští státníci věřili, že T. G. Masaryk má mimořádný vliv v celém světě a bude proto schopen vyřešit i bulharské zahraničněpolitické problémy - stát se obráncem jejich úsilí o revizi mírových smluv a zprostř̌edkovatelem zlepšení vztahů s Královstvím Srbů, Chorvatů a Slovinců (SHS). Bulharské naděje v československou pomoc lze rovněž vysvětlit okolností, že Československo nemělo s Bulharskem žádné územní spory. Bylo prvním státem, s nímž Bulharsko po Velké válce navázalo diplomatické styky. ${ }^{13} \mathrm{~V}$ neposlední řadě poválečná situace ve střední Evropě zapříčinila vznik obrazu československého státu jako pilíre Slovanstva. ${ }^{14}$

Bulharští politici a intelektuálové ale vliv Československa a jeho prvního prezidenta přecenili. Po roce 1918 se Bulharsko a Československo ocitly na opačných stranách barikády. Československá republika projevovala o bulharské záležitosti zájem z pozic člena Malé Dohody. ${ }^{15}$ I když byl T. G. Masaryk objektem kritiky kvůli svému tvrzení o možné federaci mezi Bulharskem a Jugoslávií, ${ }^{16}$ jeho autorita zůstala v bulharské společnosti vysoká. Při př́ležitosti pátého výročí vzniku Československa představitelé bulharské inteligence vyjádřili své přesvědčení, že „prezident Masaryk a ministr Beneš jsou nejpopulárnějšimi politiky v Evropě $e^{\prime \prime} .{ }^{17}$ Během svého rozhovoru s československým vyslancem v Bulharsku Bohdanem Pavlů bulharský panovník car Boris III. neskrýval „svou radost“, že se do čela republiky dostal „muž takových vlastností, jako je prezident Masaryk a že má tak schopného pomocnika, jako je ministr Beneš “ ${ }^{18} \mathrm{~V}$ této souvislosti bulharský bohemista Veličko Todorov správně tvrdí, že „po roce 1918 bylo pro Bulhary pragmatické prìklánět se z politického hlediska k Masarykovu táboru “. ${ }^{19} \mathrm{O}$ úzké spolupráci s Bulharskem ale bylo možno uvažovat pouze v hospodářské a kulturní sféře. ${ }^{20}$ Jak bulharští diplomaté v Praze a jejich českoslovenští „kolegové“ v Sofii, tak bulharští a čeští intelektuálové úspěšně uplatňovali tzv. „kulturni diplomacii“. ${ }^{21}$ Československá veřejnost také věřila, že "nejlepši př́ležitostí $k$ dalšimu sbliže-

12 Týž: Nová Europa. Brno 1994, s. 188.

13 Kolár̆, J.: K hodnoceni postoje Československa k Bulharsku, s. 155-157.

14 Např. během svého jednání s T. G. Masarykem v prosinci 1920 bulharský předseda vlády Alexander Stambolijski prosadil myšlenku vytvoření československo-jugoslávsko-bulharské federace s ústředím v Praze. Srov. Masařík, Hubert: V proměnách Evropy. Paměti československého diplomata. Praha 2002, s. 113.

15 V tehdejších diplomatických kruzích panovalo přesvědčení, že „Praha pohlíží na Balkán očima Bělehradu“. Srov. Kolár̆, Josef: Československo-bulharské vztahy v kontextu zahranični politiky v letech 1918-1938. In: Antropologie dialogu, s. 48. Např. v roce 1926 pod nátlakem Bělehradu T. G. Masaryk odmítl jednání s představitelem bulharské vlády. Masarykovy pokusy v období 1927-1928 o sblížení mezi Sofií a Bělehradem přinesly malé výsledky. Srov. Vasilev, V.: Bălgaro-čehoslovaškite političeski otnošenija, s. 26-27.

16 Masaryk, Tomáš Garrgiue: Slované po válce. Praha 1923, s. 17-18.

17 Československá republika, 1. 11. 1923, č. 301, s. 4.

18 AUTGM, f. TGM, R - cizí země, kart. 506, sl. 11 Bulharsko 1918-1928.

19 Todorov, V.: Bălgarskoto slučvane na Tomáš Garrigue Masaryk, s. 15.

20 Např. v letě 1920 se T. G. Masaryk angažoval v otázce bulharsko-jugoslávských poměrů, protože chtěl usnadnit jednání o československo-bulharském obchodním spojení. Srov. Koláŕ, J.: Bulharská demokratická emigrace v Československu, s. 21.

21 Detailně k tomu: Marholeva, K.: Obraz T. G. Masaryka v Bulharsku, s. 379-382. 
$n \imath^{\text {“ }}$ mezi Československem a Bulharskem jsou československo-bulharské kulturní styky různých institucí a organizací. ${ }^{22} \mathrm{~V}$ této souvislosti je nutno připomenout, že je kultura často definována jako „třetí pilíŕc mezinárodních vztahů. ${ }^{23}$

Bulharští vyslanci v Praze Dimităr Michalčev (1880-1967) a Boris Vazov (1873-1957) využívali svých osobních kontaktů s T. G. Masarykem, aby vytvořili jeho pozitivní obraz. ${ }^{24}$ Představitelé československo-bulharských kulturních organizací („Čech“, „Bulharsko-československá vzájemnost“, „Československý národní dům T. G. Masaryk“, „Československo-bulharská vzájemnost“) využívali státních svátků Československa, aby „inzerovali“ postavu prvního československého prezidenta. ${ }^{25}$ Hmatatelným výrazem uctívání osobnosti Masaryka v Bulharsku bylo postavení budovy ústřední organizace „Československého národního domu“ v Sofii pojmenované po Masarykovi v roce $1925 .{ }^{26}$

V meziválečném období měl první československý prezident u bulharských studentů jak v Bulharsku, tak i v Československu velký respekt. Pravicový „Bulharský národní studentský svaz“ (BNSS) ho nazval „velkým slovanským učencem“, „veřejným činitelem“, „přítelem“ bulharského národa a vysoce hodnotil Masarykovy intelektuální schopnosti

22 „Československé styky s Bulharskem “. Lidové noviny, 22. 12. 1928, č. 654, s. 4.

23 Ninkovich, Frank: Culture, Power, and Civilization: The Place of Culture in the Study of International Relations. In: Ed. R. D. Johnson: On Cultural Ground. Essays in International History. Chicago: Imprint Publications, 1994, p. 11, 17.

24 Např. D. Michalčev přednášel o Masarykovi bulharským studentům v Praze. Srov. Archiv hlavního města Prahy, Spolkový katastr X/26, Bulharská Sedjanka 1919-1954, č. j. 6471. V československém periodickém tisku představil bulharský diplomat Československo jako „nejpevnější bod ve Střední Evropě“. Srov. Michalčev, D.: Bulharsko, Československo a Jugoslávie, Československá republika, 28. 10. 1923, č. 297 , s. 8. Na základě svých neoficiálních jednání s T. G. Masarykem jej B. Vazov popisoval jako bulharofila, který projevoval zájem o makedonskou otázku. Nikolova, Veska: Dr. Boris Vazov (1873-1957). Žiznen i tvorčeski păt na politika, publicista i diplomata. V. Tărnovo 2000, s. 91 a 95. Tyto Masarykovy názory však nebyly odrazem oficiální československé politiky k makedonské otázce. Např. v interview pro Berliner Tagblatt tehdejší československý prezident prohlásil, že pro půl milionu Makedonců nevypukne v Evropě válka. Srov. Rychlík, Jan - Penčev, Vladimír - Kouba, Miroslav: Česko-bulharské vztahy. In: Ladislav Hladký a kol.: Vztahy Čechů s národy a zeměmi Jihovýchodni Evropy. Praha 2010, s. 238.

25 V roce 1919 spolek „Čech“ uspořádal kinematografické představení „Tatíček Masaryk v zahradě českých králů na Hradčanech“. Srov. Jubilejni ročenka Československé kolonie v Bulharsku, 1868-1928. Sofia, 1929, s. 81. Kromě toho zasílal T. G. Masarykovi exempláře svého časopise Československý obzor a uspořádal oslavy 28. října. V roce 1923 spolek oslavil jeho 73. narozeniny bohatým programem. Srov.: Archiv Náprstkovo muzea - Národní muzeum, Archivní sbírka krajanství, kr - Bul - I, č. 121. V roce 1925 spolek „Bulharsko-československá vzájemnost“ věnoval T. G. Masarykovi první číslo svého časopisu a uspořádal oslavy jeho 75. narozenin. Srov. Jubilejni ročenka Československé kolonie v Bulharsku, s. 132-133; „Dopis z Bulharska“. Národní listy, 4. 4. 1925, večerní vydání, č. 93, s. 1. Výstava bulharských malířu v Praze následujícího roku uspořádaná spolkem „Československo-bulharské vzájemnosti“ proběhla během oslav 76. narozenin československého prezidenta. Srov. Badžov, Stefan: Bălgarskata hudožestvena izložba v Praga, Bălgarsko-čehoslovaška vzajimnost 2,1926 , č. 2-3, s. 17.

26 Jubilejni ročenka Československé kolonie v Bulharsku, s. 147. Sofijská organizace „Československý národní dům“ založila svoje odbočky v českých a slovenských koloniích. V první polovině 30. let v slovenských vesnicích Mrtvici (Severní Bulharsko) a Gorni Mitropolii a v české vesnici Vojvodově byly slavnostně otevřeny budovy Československého národního domu „T. G. Masaryka“. Srov. AUTGM, fond Edvard Beně̌ (dále f. EB), odd. I, sign. R 289, Bulharsko 1935-1938, kart. 149, sl. 686. „Československo-bulharská kronika“, Československo-bulharská vzájemnost 1934, č. 4, s. 42. Čeští a slovenští žáci v tamějších školách se každoročně účastnili oslav u příležitosti výročí vzniku Československa a narozenin prezidenta T. G. Masaryka. Srov. Moravcová, Ilona: Obrázky z dějiny českého menšinového školstvi v zahraniči. Pardubice 2006, s. 46-47. 
a jeho kladný postoj k Bulharsku. V roce 1931 se T. G. Masaryk stal čestným předsedou „Svazu bulharských studentských spolků v Československu“..27

Idealizace a mytologizace Masarykovy postavy v meziválečném Bulharsku dosáhla bezpochyby svého vrcholu během oslav jeho 80. narozenin. Tyto oslavy ukázaly, že Bulhaři neztratili svoji víru v schopnost prvního československého prezidenta přispět k realizaci bulharských národních aspirací. Oslavy v Bulharsku proběhly jednak jako veřejný rituál, jednak jako intelektuální diskurz prostřednictvím publikací představitelů bulharské inteligence. ${ }^{28}$ Masarykův obraz byl konstruován bulharskými a českými intelektuály, politiky a diplomaty (bulharský filozof a diplomat Dimităr Michalčev, bulharští literární historíci Alexandăr Balabanov a Boris Jocov, bulharský politik Stojan Danev, tehdejší bulharský vyslanec v Praze Boris Vazov, český novinář Vladimir Sís, československý vyslanec v Bulharsku Václav Rejholec a další), kteří spojili obrazy prvního československého prezidenta a Československa a zároveň vytvořili komplexní Masarykův životopis - T. G. Masaryk byl popsán jako univerzitní profesor, vědecký pracovník, bulharofil, politik, obránce lidských práv, stoupenec slovanské politiky a v neposlední řadě jako mesiáš, který byl Prozřetelností poslán, aby převzal úlohu ochránce malých slovanských národů. Československo bylo představeno jako model vhodný k následování pro ostatní slovanské státy v otázce jeho tolerantní politiky vưči menšinám. ${ }^{29}$

Velkým přínosem k sblížení Bulharska a Československa na přelomu 20. a 30. let měl bulharský panovník Boris III. V roce 1928 vyjádřil tehdejšímu československému vyslanci v Bulharsku Václavu Rejholcovi přesvědčení, že „svou rozvážnou a smířlivou politikou“ slouží československý stát jako př́íklad politické vyspělosti a „skutečně přispívá ke zlepšení poměrů mezi slovanskými státy“ “ ${ }^{30} \mathrm{~V}$ tomto období se uvažovalo i o možné návštěvě československého prezidenta v Bulharsku. K podobné návštěvě nikdy nedošlo, prý kvůli Masarykově zhoršujícímu se zdravotnímu stavu, ${ }^{31}$ ale spíše z politických důvodů. Jednání mezi československým prezidentem a bulharským panovníkem v roce 1929 v Praze a korespondence mezi nimi v období $1929-1932^{32}$ svědčí nejen o intenzivnějším vývoji česko-

27 „Predsedateljat na Českoslovaškata republika pokrovitel na bălgarskite studenti v Čechija“. Studentska borba, 3. 5. 1931, č. 13, s. 1.

28 Hlavními iniciátory veřejných oslav, které proběhly v bulharské akademii věd, byly „Bulharsko-československá vzájemnost“ a Československý národní dům T. G. Masaryka. Oslav se zúčastnil bulharský král Boris III., představitelé bulharské vlády a diplomatů, první bulharský charge d'affaire Bulharska v Československu a tehdejší rektor Univerzity v Sofii profesor Stefan Balamezov, tehdejší československý vyslanec v Bulharsku V. Rejholec a další. Srov. Marholeva, K.: Obraz T. G. Masaryka v Bulharsku, s. 385.

29 Tamtéž, s. 385-394.

30 AUTGM, f. TGM, R - cizí země, kart. 506, sl. 11 Bulharsko 1918-1928.

31 Bulharský král Boris T. G. Masarykovi, 1930, 15. září, in: Edd. L. Hladký - J. Škerlová - P. Cibulka: Korespondence T. G. Masaryk-Slované: Jižní Slované, Praha 2015, dok. 328, s. 414; T. G. Masaryk bulharskému králi Borisovi, 1930, 15. září, in: tamtéž, dok. 329, s. 415.

32 Bulharský král Boris T. G. Masarykovi 1929, 16. června, in: tamtéž, dok. 303, s. 389; T. G. Masaryk bulharskému králi Borisovi, 1929, 30. září, in: tamtéž, dok. 304, s. 390; Bulharský král Boris T. G. Masarykovi 1929, 19. prosince, in: tamtéž, dok. 306, s. 393; Bulharský král Boris T. G. Masarykovi 1932, 28. června, in: tamtéž, dok. 381, s. 445-446; T. G. Masaryk bulharskému králi Borisovi, 1932, 23. července, in: tamtéž, dok. 362, s. 446-447. 
slovensko-bulharských diplomatických vztahů v politické sféře, ale i o tom, že Masarykův postoj k Bulharsku zůstal kladný.

Ve 30. letech tehdejší diplomat československého vyslanectví v Bulharsku Hubert Masařík charakterizoval bulharského panovníka jako skvělého a zkušeného psychologa pokud jde o jeho vztahy k cizím diplomatům: „Našeho vyslance Prokopa Maxu, ctitele T. G. Masaryka, [car Boris III. pozn. aut.] prijímal vždy tak, že měl na psacím stole velký Masarykưv portrét a obvykle jakoby poznamenal, že se považuje za malého žáka československého prezidenta. "33 V souvislosti se zhoršením zdravotního stavu T. G. Masaryka v roce 1934 byl P. Maxa ohromen projeveným hlubokým zájmem bulharského panovníka. ${ }^{34}$ Následujícího roku car Boris III. znovu vyjádřil svůj obdiv k československému prezidentovi, když se aktivně zúčastnil oslav při příležitosti jeho 85 . narozenin. ${ }^{35}$

Zvolení T. G. Masaryka prezidentem v roce 1934 bylo v bulharském tisku hodnoceno jednak jako mimořádná událost a precedent v světových politických dějinách, jednak jako výraz vděčnosti československého národa k „velikému člověku, který vytvořil nový stát“. Československý prezident byl charakterizován jako jediná politická postava, která je schopna konsolidovat vnitřněpolitický život Československa. ${ }^{36}$

Osobnost T. G. Masaryka byla předmětem obdivu a idealizace v Bulharsku během oslav u příležitosti jeho 85. narozenin. ${ }^{37}$ Jeho obraz a obraz Československa byly záměrně spojeny. Bulharský periodický tisk ho popsal jako pokračovatele Jana Husa, Jana Amose Komenského a Františka Palackého, stoupence slovanské solidárnosti, bulharofila, ${ }^{38}$ bojovníka proti Habsburkům, nazval ho „architektem Československa“, ${ }^{39}$ státníkem a Evropanem, „národní hrdinou“ „velkým státníkem Československa“, „skutečným šéfem československého národa“, a jeho zvolení prezidenta v roce 1934 nazval „triumfální manifestací národní jednoty“..0 U příležitosti Masarykova životního jubilea byl vydán v Bulharsku knižně jeho obsáhlý životopis. ${ }^{41}$

33 Masařík, H.: V proměnách Europy, s. 143.

34 AUTGM, f. EB, odd. I, sign. R 288, Bulharsko 1933-1934, kart. 148, sl. 684.

35 Srov. Masarikovata 85-godišnina i Bălgarija, Slavjanski glas 1935, č. 2, s. 81-83.

36 B. V. [= Boris Vazov]: Preizbiraneto na prezident Masarik. Mir, 23. 5. 1934, č. 10155, s. 3.

37 Oslavy v Sofii uspořádaly „Bulharsko-československá vzájemnost“ a Československý národní dům „T. G. Masaryka“ v bulharské akademii věd. Na oslavách promluvili bývalý bulharský vyslanec v Praze B. Vazov, univerzitní profesor B. Jocov a československý vyslanec v Sofii P. Maxa. Slovanský dobročinný spolek poslal Masarykovi dopis, v němž uvedl, že jeho osobnost je kombinací „velkého filozofa a moudrého státníka“ poslaného Prozřetelností. Srov. „Predsedateljat Masarik“. Mir, 7. 3. 1935, č. 10390, s. 3; „Masarikovata 85-godišnina i Bălgarija“. Slavjanski glas 1935, č. 2, s. 81-83. Podobně jako v roce 1930, se oslav zúčastnili i představitelé bulharské inteligence. O poměru Masaryka k ženám promluvila bulharská spisovatelka Dora Gabe, která měla na svůj pobyt v Praze v roce 1931 hezké vzpomínky, kdy měla možnost setkat se s československým prezidentem osobně. Srov. „Oslavy 85. narozenin pana prezidenta republiky T. G. Masaryka“, Pražské noviny, 9. 3. 1935, č. 58, s. 1-2.

38 Dorev, Pančo: Prezident Masarik. Zora, 6. 3. 1935, č. 4703, s. 6.

39 Štajnhard, A.: T. G. Masarik - syzdatel na čehoslovaškata dyržava. Slovo, 6. 3. 1935, č. 3803, s. 1.

40 „Predsedateljat Masarik“. Mir, 7. 3. 1935, č. 10390, s. 3.

41 Vălkov, Georgi: T. G. Masarik 7. III. 1850-7. III. 1935. Sofija 1935. 
Masarykovu abdikaci roku 1935 oznámily bulharské noviny s lítostí, protože „celý svět už dávno spojoval Československo s jeho postavou“, a dokonce jej nazývaly „Československem Masarykovým“. Bylo prý „těžko najit kandidáta, který by ho jako prezidenta nahradil“. ${ }^{2}$ První československý prezident byl charakterizován jako jeden z malá státníků, který byl objektem všeobecného respektu svých krajanů. ${ }^{43}$ Masarykova postava zůstala mezi Bulhary objektem obdivu i po jeho abdikaci. V předvečer Masarykových 87. narozenin car Boris III. vyjádřil P. Maxovi svůj respekt k Masarykovi a jeho následovníku E. Benešovi. „O prezidentu Osvoboditeli mluvi vždy s oddanou úctou“, tvrdil československý diplomat. ${ }^{44}$ V březnu 1937 bulharský slavjanofilský tisk popsal T. G. Masaryka jako „jednoho z nejlepšich prátel Bulharska“, který „podporoval Bulharsko při každé př́ležitosti“ “45

Ve 30. letech přispěl k uplatňování kulturní diplomacie mezi Československem a Bulharskem československý vyslanec Prokop Maxa ve spolupráci s bulharsko-československými kulturními organizacemi. ${ }^{46} \mathrm{~V}$ úvodníku zvláštního čísla Lidových novin v roce 1935 věnovaného Bulharsku P. Maxa uvedl, že nejpřesvědčivějším důkazem intenzivních bilaterálních vztahů jsou politické, obchodní a kulturní smlouvy a dohody podepsané oběma státy. ${ }^{47}$ Jednou z bilaterálních smluv byla bulharsko-československá tisková dohoda podepsaná v Praze v lednu roku 1935, jejímž cílem bylo „vzájemné poznání obou států“ v politické, hospodářské, sociální a duchovní sféře. ${ }^{48} \mathrm{Na}$ základě této dohody v září roku 1936 odjelo do Sofie 15 československých novinářů vedených Vladimírem Sísem ${ }^{49}$ Bylo rozhodnuto, že následující rok 1937 bulharští novináři „oplatí“ svým československým kolegům návštěvu a přijedu do Československa.

\section{„Kult mrtvého hrdiny" - reflexe Masarykovy smrti v Bulharsku}

Dne 6. září 1937 vstoupilo 13 bulharských novinářů v čele s předsedou sofijského výboru bulharsko-československé tiskové dohody Georgiem Belčevem na půdu Československa. Jak bylo uvedeno v bulharském tisku, jejich hlavním cílem byla účast na československo-bulharské tiskové konferenci v Praze. Bulharští novináři zároveň neskrývali svoji radost, že mezi oběma státy existuje úzká mezikulturní spolupráce, a ne konflikty a nedorozu-

42 Mir, 14. 12. 1935, č. 10622, s. 2.

43 „Edin goljam dăržavnik“, Mir, 18. 12. 1935, č. 10625, s. 1.

44 AUTGM, f. EB, odd. I, sign. R 289, Bulharsko 1935-1938, kart. 149, sl. 687.

45 „Osemdeset $i$ sedem godišnija den na prof. Tomaš Garik Masarik“. Slavjanski vesti, 1. 4. 1937, č. 13, s. 5-6.

46 V dubnu a v květnu roku 1936 v sále Slovanské besedy byl uspořádán cyklus přednášek věnovaných T. G. Masarykovi Československu. Srov. NA v Praze, f. MŠANO, kart. 3548, č. j. 70683.

47 Maxa, P.: Československo a Bulharsko. Lidové noviny, 11. 5. 1935, č. 237, s. 1.

48 „Československo-bulharská tisková dohoda“. Lidové noviny, 23. 1. 1935, č. 40, s. 2.

49 Zlateva, Ani: Vladimir Sís i češko-balgarskite otnošenija ot 20-30-te godini na XX vek. In: Roljata na češkata inteligencija v obštestvenija život na sledosvoboždenska Balgarija. Praha 2008, s. 218; Slavjanski kalendar za 1937 godina, s. 73. Po dvoutýdenním pobytu čeští novináři navštívili Rilský klášter, druhé největší město Bulharska Plovdiv, český cukrovar Horné v Orjahovici, Veliko Trnovo a Varnu. Srov. „Českoslovenšti novinári v Bulharsku“. Národní listy, 20. 9. 1936, č. 258, s. 3. 
mění. ${ }^{50} \mathrm{Z}$ Bulharska přijeli Boris Andrejev (zástupce bulharského tisku), Jordan Mečkarov (předseda Sdružení sofijských novinářů), Georgij Belčev, Todor Kožucharov (Slovo $\left.{ }^{51}\right)$, Vasil Pavurdžijev a Boris Rumenov $\left(\right.$ Zarija $\left.^{52}\right)$, Venceslav Protič (Dnes), Boris Kirov (Utro $\left.{ }^{53}\right)$, Christo Brăzicov $\left(M_{i r}^{54}\right)$, Lazar Popovski (Nova Kambana), Jordan Badev $\left(\right.$ Zora $\left.^{55}\right)$, Ivan Genadijev (zástupce Bulharské tiskové kanceláře) a další. Dr. Doležal z československého ministerstva zahraničních věcí pozdravil bulharské hosty v češtině a bulharštině a vyjádřil naději, že „si odnesou nejlepši dojmy a stanou se dobrými prostředniky v úzkých stycích mezi oběma národy a státy “. ${ }^{56}$ Dalším cílem zájezdu bylo, aby ve dnech 6.-18. září bulharští novináři navštívili některá významnější místa v Československu. ${ }^{57}$ Československý tisk vyjádřil přání, aby se bulharským novinářům v Československu „co nejvíce líbilo a aby jejich studijni cesta [...] dala podnět $k$ dalšimu sbliženi obou slovanských státư. "Výprava přijela do Bratislavy a pak pokračovala do Brna. Bulharští novináři strávili na Moravě dva dny. ${ }^{58}$

Svou návštěvou Československa se bulharští novináři ocitli v kuriózní situaci - vstoupili na jeho území pouze několik dnů po uveřejnění první zprávy o zhoršení zdravotního stavu T. G. Masaryka v československém tisku. ${ }^{59}$ Nepředpokládali však, že během jejich pobytu v Československé republice T. G. Masaryk zemře. Při svém př́ijezdu do Brna zaslali T. G. Masarykovi telegram, v němž vyjádřili své přesvědčení, že svoji nemoc překoná: „Vážený pane prezidente Osvoboditeli! Vstupujice na územi Československa, my, bulharšti novinář́, př́pojujeme své city obdivu $k$ citům celého národa československého a spolu s ním vznášime vroucí modlitby $k$ V̌̌emohoucímu, aby Vám ještě na dlouhá léta zachoval zdravi $k$ prospěchu bratrského národa a celého lidství, jemuž Vy, pane prezidente, jste zasvětil svưj dlouhý a bojů plný život. "60

Po svém návratu do Prahy bulharští novináři položili věnec ke hrobu Neznámého vojína na Staroměstské radnici. ${ }^{61}$ Pak navštívili pražské výstaviště, kde bylo slavnostně odhaleno bulharské oddělení pražské podzimní výstavy pod záštitou bulharského panovníka Borise III. a bulharského vyslance v Praze Petra Nejkova, který vyjádřil svoji radost

50 „Konferencija po pečata“. Slovo, 6. 9. 1937, č. 4552, s. 1.

51 Noviny Slovo byly založený v roce 1922 bulharským diplomatem Alexandrem Grekovem. Psali do něj bulharští intelektuálové, bývalí předsedové pravicových vlád v meziválečném Bulharsku Alexander Cankov a Andrej Ljapčev a další.

52 Noviny Zarja vycházely v období 1914-1944.

53 Noviny Utro byly nestranickým deníkem, který vycházel v období 1911-1944.

54 Noviny Mir byly založeny roku 1894 jako periodický orgán bulharské lidové strany. V meziválečném období byly nazývány „bulharským Timesem“. Srov. http://paper.standartnews.com/archive/2001/06/11/ history/s3034_4.htm, citováno 15. 9. 2014.

55 Zora byly nezávislé noviny, založené známým bulharským publicistou Danailem Krapčevem v roce 1919 a vycházely až do roku 1944.

56 „Bulharští novináři v Československu“. Venkov, 7. 9. 1937, č. 210, s. 5; „Zájezd bulharských novinář̃o do Československa“. Pražské noviny, 7. 9. 1937, č. 208, s. 2.

57 „Bulharšti novináři v Československu“. Venkov, 7. 9. 1937, č. 210, s. 5.

58 „Bulharšti novináři v Praze“. Venkov, 8. 9. 1937, č. 211, s. 5.

59 První zprávy o zhoršení zdravotního stavu T. G. Masaryka byly uveřejněné 3. 9. 1937. Srov. „Vážné onemocněni prezidenta Osvoboditele“. Pražské noviny, 3. 9. 1937, č. 205, s. 1.

60 „Pozdrav bulharských novinárư “. Lidové noviny, 7. 9. 1937, č. 449, s. 2.

61 „Bulharšti novináři naďseni Československem“. Venkov, 9. 9. 1937, č. 212, s. 4. 
z podepsané obchodní smlouvy mezi Bulharskem a Československem na jaře 1937.62 Bulharští novináři byli v Černínském paláci přijati československým ministrem zahraničí K. Kroftou a předsedou československé vlády M. Hodžou, který vyslovil naději, že jejich př́jjezd přispěje k pohloubení vzájemných styků mezi oběma státy. ${ }^{63}$

O zájezdu bulharských novinářů po Československu informoval podrobně bulharský periodický tisk. Na stránkách slavjanofilských novin Mir jeho hlavní redaktor Christo Brăzicov popsal své dojmy z cesty po Moravě. Ve svém textu neskrýval své nadšení z přírody Československa - nazýval Bratislavu „českou královnou Dunaje“ a Brno - „druhým hlavním městem Československa“. ${ }^{4}$ Protože v této době byl T. G. Masaryk už vážně nemocný, vyjádření obdivu k vřelé pohostinnosti v Československu kontrastovalo se starostí o zdravotní stav bývalého československého prezidenta. Např. Christo Brăzicov popisoval „velkolepé staré budovy“ v Brně, kde „bloudí Masarykův duch“. Tam člověk „potká“ všude Masarykovo jméno - Masarykovu dívčí školu, Masarykovu univerzitu, Masarykovu ulici, po Masarykovi byla pojmenována i jedna brněnská čtvrt. „Za Masaryka se už několik dnů modli vroucně všichni Čechoslováci“, uvedl dále přední bulharský publicista. ${ }^{65}$ Christo Brăzicov charakterizoval Masarykův život krátkým, ale originálním způsobem: „Ten syn kočího ve svém dětstvi zanechal kovářské řemeslo, aby se věnoval vědě a pak se stal kovářrem osudu svého národa. “66 T. G. Masaryk a Československo byly představeny jako „děti Prozřetelnosti“: Masaryk byl prý „muž československého národa zvolený osudem“ a první světová válka byla „událost poslaná nebem“. ${ }^{67}$

V další zprávě Christa Brăzicova psané v době, kdy byl T. G. Masaryk ještě naživu, a uveřejněné po jeho smrti dominovaly dva protikladné pohledy - nadšení a frustrace. Na jedné straně bulharský publicista neskrýval svůj obdiv k „modernímu státu, nádherné přirodě, svěžesti Karlových Varů a Mariánských Lázni, hlavnímu městu piva Plzně, továrnám „Škoda“, „Masarykovým domovům“. Na druhé straně popsal smutnou atmosféru v Praze v předvečer Masarykovy smrti a zoufalství, které panovalo mezi lidmi kvůli blížícímu se Masarykovu konci: „Tatiček Masaryk je na smrtelné posteli“. „Každou půlhodinu noviny informovaly o Masarykově boji se smrti. “ „Každý okamžik se dá očekávat hrozná zpráva. "68 Podobně jako na oslavách v roce 1930 a v roce 1935, i v tomto případě byly záměrně spojeny obrazy Masaryka a Československa. Chr. Brăzicov charakterizoval Československou republiku jako „Masarykovo dílo“ a svoji představu o československých dějinách si vytvořil na základě obrazu prvního československého prezidenta. Můžeme říct, že svými články bulharský intelektuál hodnotil celkový Masarykův život, jako by cítil blížící se smrt prvního československého prezidenta. Cestu bulharských novinářů po Československu lze

62 „Bălgarskite žurnalisti v Praga“. Slovo, 10. 9. 1937, č. 4556, s. 3.

63 „Denni zprávy“. Pražské noviny, 11. 9. 1937, č. 212, s. 5.

64 B[răzicov], Chr[isto]: Părvi stăpki v Čechoslovakia. Sărdečen prijem v Brno. Obožavaneto na Masarik. Pogled iz Brno. Mir, 10. 9. 1937, č. 11140, s. 1.

65 Tamtéž.

66 Tamtéž.

67 Tamtéž.

68 Brăzicov, Christo: Iz čehoslovaškata zemija (Pătuvane na vestnikarite). Pokraj letovišta $i$ zamăci. Masarikovi domove. Vseobšti obič i tăga. Mir, 17. 9. 1937, č. 11145, s. 1. 
tedy charakterizovat jako symbolické rozloučení se s T. G. Masarykem a veřejný projev jejich úcty k politickému, hospodářskému a kulturnímu dědictví, které po sobě Masaryk zanechal.

Posledních několik dnů života T. G. Masaryka bylo velmi podrobně a pečlivě zaznamenáváno nejen v Československu, ale i v celém světě, včetně Bulharska. Jak Pražské noviny uvedly, bulharský tisk „sledoval s neobyčejným zájmem i účastí průběh nemoci prezidenta Osvoboditele Masaryka, který se v celém Bulharsku vždy těšil mimořádné úctě ${ }^{\text {r. }}{ }^{69} \mathrm{~V}$ bulharských novinách se informace o zdravotním stavu prvního československého prezidenta znovu objevila 13. září. Mir a Slovo uvedly, že podle oficiálních zpráv osobního lékaře ze dne 12. 9. v 18:30 hodin je zdravotní stav bývalého prezidenta stabilní. Tyto zprávy vyvolaly u lidí, který se shromáždil před zámkem v Lánech, velkou naději. ${ }^{70}$

O zdravotním stavu T. G. Masaryka podával pravidelné zprávy československý rozhlas. ${ }^{71}$ „Tak jako celá veřejnost, sleduji všechny listy s úzkostlivou vážností vývoj zdravotního stavu prezidenta-osvoboditele Masaryka, který se náhle v noci na včerejšek zhoršil částečným zápalem plic. “ Tato zpráva zněla 13. září z rozhlasových přijímačů v Československu celý den. Posluchači se dozvěděli i to, že v Lánech byla celá rodina T. G. Masaryka, československý prezident E. Beneš s manželkou a premiér Milan Hodža. Do Lán i na Pražský hrad přicházely tisíce telefonických dotazů a také oficiální telegramy ze zahraničí. Mezi projevy, které došly do Lán, byl také telegram bulharského cara Borise. ${ }^{72}$

V noci 14. zář́i 1937 první československý prezident zemřel. Zpráva o jeho smrti se rozletěla do světa poté, co ji novinářům 14. září ráno oznámil Masarykův syn Jan těmito prostými slovy: „Otec skonal ve 3 hodiny 29 minut. “73 Československý tisk přinesl téhož dne první smuteční zprávy. Národni listy uveřejnily na první stránce velkou podobiznu zesnulého Masaryka, podrobně popsaly jeho život a politickou činnost a uvedly, že u lože umírajícího prezidenta byli shromáždění všichni členové jeho rodiny, prezident E. Beneš a předseda vlády M. Hodža. ${ }^{74}$ Československý rozhlas vysílal smuteční hudbu a po celém Československu se konaly smuteční církevní bohoslužby. ${ }^{75}$

Smrt T. G. Masaryka představovala bezpochyby událost, která přitahovala pozornost nejen československé veřejnosti, ale celého světa. ${ }^{76}$ Československý prezident Edvard Beneš obdržel kondolenční telegramy od zahraničních státníků a politických osobností. Bývalý bulharský car Ferdinand, který v té době žil na Slovensku, ${ }^{77}$ poslal svoji písemnou

69 „Velká účast z ciziny, Bulharsko“. Pražské noviny, 15. 9. 1937, č. 216, s. 5.

70 „Čechoslovakia. Položenieto na Masarik“. Mir, 13. 9. 1937, č. 11142, s. 2; „Săstojanieto na Masarik ne se e vlošilo“. Slovo, 13. 9. 1937, č. 4558, s. 3.

71 Hájková, D.: Constructing National Unity, s. 40, 42.

72 http://www.rozhlas.cz/zpravy/historie/_zprava/pred-75-lety-zemrel-prvni-ceskoslovensky-prezident-t-g-masaryk-1110299, citováno 20. 5. 2014.

73 Tamtéž.

74 „T. G. Masaryk“. Národní listy, 14. 9. 1937.

75 Hájková, D.: Constructing National Unity, s. 42.

76 „T. G. Masaryk“. Národní listy, 14. 9. 1937.

77 Po porážce Bulharska ve Velké válce byl Ferdinand přinucen k abdikace ve prospěch svého syna Borise. Rod Sasko-Kobursko-Gothajský měl mj. své rodové statky také na středním Slovensku, a Ferdinand na nich 
kondolenci: „Prosím Vaši Excelenci, abyste prijal $k$ úmrti svého vynikajicího předchůdce a věrného přitele mou nejupř́mnějši soustrast. “78

Bylo stanoveno, že se pohřeb zesnulého T. G. Masaryka bude konat v úterý 21. září a nad rakví svého předchůdce promluví československý prezident E. Beneš. ${ }^{79}$ Noviny uvedly, že rakev zesnulého Masaryka bude vystavena ve dnech 18., 19. a 20. záŕí ve sloupové síni Pražského hradu. Bylo rozhodnuto, že v pondělí 20. září se přijdou poklonit památce zesnulého prvního československého prezidenta ke katafalku na Hradě členové Národního shromáždění. ${ }^{80}$ Den před pohřbem předseda československé sněmovny Jan Malypetr uvedl, že po své smrti bude T. G. Masaryk „s námi myšlenkově a duchovne““ 81

Zástupci bulharských žurnalistů B. Andreev, J. Mečkarov a G. Belčev se dostavili k zpravodajskému odboru ministerstva zahraničních věcí, aby vyjádřili hlubokou účast bulharských žurnalistů nad úmrtím prezidenta-Osvoboditele. Vzhledem k národnímu smutku v Československu přerušili bulharští novináři svo̊j studijní pobyt v Československu. ${ }^{82}$ Nicméně díky své přítomnosti v Praze během Masarykovy nemoci a smrti bulharští novináři zažili smutnou atmosféru a přinášeli o Masarykovi hodně informaci.

O zesnulém Masarykovi psal veškerý bulharský tisk - Mir, Slovo, Zarja, Zora, Utro, La Parole Bulgare a další. ${ }^{83}$ První zprávy o Masarykově smrti se objevily v bulharském periodickém tisku již 14. září v denicích Slovo a Mir. V Slovo jeden z bulharských novinářů, bývalý ministr Todor Kožucharov (1891-1945), popsal poslední chvíle „velkého státníka“: „Členové rodiny políbili ruku a čelo zesnulého. P[an] Beneš políbil čelo vynikajicího zesnulého. Předseda vlády p. Hodža se hluboce poklonil. Masarykova dcera Alice požádala osobního lékáře MUDr Maixnera, aby zavřel zesnulému oči. “84 T. Kožucharov zároveň charakterizoval atmosféru v Praze jako smutně slavnostní: „Zpráva o smrti prezidenta Masaryka vyvolala v Československu silné vzrušení. Navzodry pozdnímu času bylo před sídlem prezidenta plno lidí. Když byla vlajka nad budovou stažena do půl žerdi, všichni pochopili, že přišel konec. Ženy a muži padli v slzách na kolena. Celá republika cítila, že ztratila nejen svého prezidenta-Osvoboditele a otce národa, ale i jednoho z nejvznešenějších duchů našeho období, kdo přinesl československou nezávislost a získal si obdiv celého civilizovaného světa.“ „U lože zesnulého stojí jako čestná stráž českoslovanští legionáři, kteří bojovali v [první] světové válce. Tvář velkého starého muže osvětlují svíčky." 85

Tuto informaci o Masarykově smrti uveřejnily i noviny Mir a dodaly, že tělo zesnulého prezidenta-Osvoboditele bude balzamováno a sochařem Makovským bude sňata po-

od roku 1934 se souhlasem československé vlády často pobýval a žil tam několik let, protože byl okouzlen slovenskou přírodou. Detailně k tomu: Holec, Roman: Coburgovci a Slovensko. Bratislava 2010, s. 266-268.

Pražské noviny, 18. 9. 1937, č. 291, s. 2.

„Pohřeb prezidenta Osvoboditele v útery“. Pražské noviny, 17. 9. 1937, č. 218, s. 1.

„Lid se rozlouči se suým prezidentem osvoboditelem“. Pražské noviny, 18. 9. 1937, č. 219, s. 1.

Hájková, D.: Constructing National Unity, s. 40-41.

Národni listy, 15. 9. 1937, s. 3.

Legální levicový tisk v této době nevycházel. Po státním převratu roku 1934 byly bulharské politické strany a část periodického tisku zakázány a byla zavedena přísná cenzura.

Kožucharov, T.: Masarik, osvoboditeljat na Čehoslovakija, počina. Slovo, 14. 9. 1937, č. 4559, s. 3.

Tamtéž. 
smrtná maska. ${ }^{86}$ Dne 15. září hlavní redaktor novin Mir Christo Brăzicov rovněž popsal smutnou atmosféru v Praze, která po smrti T. G. Masaryka panovala. Jeho zpráva byla ale uveřejněna v Bulharsku až 20. září: „V noci mezi 13. a 14. zář́ [československý] rozhlas sdělil celému světu zprávu o smrti velkého světoobčana T. G. Masaryka, kterého celý československý národ obdivoval. Již v 6 hodin ráno se lidé pohybovali po ulicích mezi visícimi černými vlajkami. V̌sechny obchodni výlohy byly dekorovány černou barvou. Masarykưv obraz bylo vidět na všech obchodnich výlohách v Praze“. Chr. Brăzicov byl ohromen, že jak levicové, tak pravicové noviny vyjadřovaly společně svůj smutek. Na přání zesnulého prezidenta jeho tělo bude pohřbeno na zámku v Lánech, vedle jeho dávno zesnulé choti, nikoliv na hřbitově českých králů, jak si národ přál, uvedl dále autor. ${ }^{87}$

V novinách Zora byly dne 15. září na první stránce uveřejněné podobizny T. G. Masaryka. Úvodníky byly věnovány prvnímu československému prezidentu. „Zemřel velký člověk a státnik“. Jeho životní příběh musí sloužit jako příklad všem, kteří chtějí věnovat svůj život své vlasti, zněly úvodní slova v novinách Zora. V úvodníku byl uveřejněn krátký Masarykův životopis. ${ }^{88} \mathrm{~V}$ dalším článku bulharský novinář Jordan Badev podal detailní zprávy o posledních chvílích zesnulého prezidenta, o smuteční atmosféře v Praze, o zármutku, který panoval mezi lidmi; o detailech kolem pohřbu a kondolenčních telegramech, které bulharský panovník a členové bulharské vlády poslali prezidentu E. Benešovi a rodině T. G. Masaryka. ${ }^{89}$

Dne 16. září byl v novinách Mir podrobně publikován projev československého předsedy vlády M. Hodži u př́iležitosti smrti T. G. Masaryka. M. Hodža připomněl „velkých bojů, které vedl Masaryk během svého života jako vĩdce českého národa“ a uvedl: „Anglie a Francie uznávaji, že Masaryk byl pilírem, nad kterým byl most, spojujici západni evropské a východoevropské civilizace [...], intelektuálním meznikem mezi slovanskou a německou kulturou." Noviny Mir dále uveřejnily Hodžovu výzvu, že všichni mají přijmout jako všenárodní povinnost chránit ideály, za něž první československý prezident bojoval, zůstat jednotní a obhajovat československou demokracii a parlamentarismus. ${ }^{90}$

Bulharská kolonie v Praze také veřejně vyjádřila svůj smutek a úctu k zesnulému prvnímu československému prezidentovi. V polovině listopadu navštívilo 50 bulharských studentů Lány a položilo věnec na hrob zesnulého Masaryka. Poté si bulharští studenti prohlédli zámek a výstava bývalého československého prezidenta. ${ }^{91}$ Jeden z předních představitelů bulharské kolonie v Československu, známý bulharský básník Kiril Christov (1875-1944), který v 30. letech žil v Praze a působil jako lektor bulharského jazyka na Univerzitě Karlové, věnoval památce zesnulého československého prezidenta báseň „Masarykovu národu“, uveřejněnou v listopadovém číslu časopisu „Československo-bulharská vzájemnost“.

86 „Čechoslovakija, Masarik počinal“. Mir, 14. 9. 1937, č. 11143, s. 2.

87 Brăzicov, Christo: Praga v černo (Ot našija pratenik v Čehoslovakija). Mir, 20. 9. 1937, č. 11148, s. 3.

88 „Tomaš Garik Masarik“. Zora, 15. 9. 1937, č. 5462, s. 1.

89 Badev, Jordan: Počina părvijat meždu părvite sinove na Čehoslovaško. Zora, 15. 9. 1937, č. 5462, s. 1, 3.

90 „Skrăbta za predsedatelja Masarik“. Mir, 16. 9. 1937, č. 11145, s. 2.

91 „Denni zprávy“. Český deník, 19. 11. 1937; „Kak rabotjat bălg[arskite] studenti v čužbina“. Čechoslovaško. Akademik, [s. d.] 1938, s. 2. 


\section{KIRIL CHRISTOV:}

Masarykovu národu

Z bulharštiny přel. Jiřína Karasová

„Zřím v údivu a dojat řadu roků:

kde moudrý přejde, vtlačí stopu kroku, jde národ za ním na vzestupu cest, jenž důstojného vůdce hoden jest. Já viděl sklíčenost a bolest sirá jak přímo z hlubin duše rozedírá, že přírodních řád věčných zákonů vzal vzácnou obět zvonů za stonu.

A k tobě nyní celičky svět hleděl, svět celý tvému žalu odpověděl: ty - v zármutku svém duši odhaliv jsi svým i cizím milejší než dřív! A nekonečný žal mi srdce svírá, že není všude v světě stejná míra: že jiný národ, kde tma předivem, ubijí přední syny v středu svém“. ${ }^{92}$

Na počest úmrtí T. G. Masaryka byla dne 16. září na sofijském zámku carská vlajka stažena na půl žerdi. V sofijském rozhlase vystoupila bulharská básnířka Dora Gabe (18881983) na téma „Několik myšlenek velkého mrtvého“.${ }^{93}$ D. Gabe pak promluvila o svých osobních vzpomínkách na T. G. Masaryka, připomněla jeho přátelský vztah k Bulharsku a zejména jeho snahy o usmíření Bulharska a Srbska po druhé balkánské válce ${ }^{94}$ Bulharský tisk dále informoval, že dne 19. září připravují kulturní organizací sofijských Čechů v budově Československého národního domu „T. G. Masaryka“ zádušní mši (panychidu) na památku zesnulého prezidenta, na níž promluví P. Maxa. ${ }^{95}$

V den pohřbu T. G. Masaryka v Praze 21. září se v sofijském katolickém kostele svatého Josefa konala panychida, na níž byli přítomni bulharští ministři, cizí diplomaté, úředníci bulharského ministerstva zahraničí atd. ${ }^{96}$ Téhož dne spolek „Bulharsko-československá vzájemnost“ v Sofii uspořádal ve velkém sále Akademie věd oficiální smuteční slavnost za prezidenta Osvoboditele. Bulharský car Boris III. opustil své letní sídlo nedaleko Varny (palác Euksinograd), aby se smuteční slavnosti zúčastnil. ${ }^{97}$ Po jeho přícho-

92 Christov, Kiril: „Masarykovu národu“. Československo-bulharská vzájemnost, listopad 1937, č. 3, s. 1.

93 Bulharsko: Masarykova památka bude věčně žít. Pražské noviny, 17. 9. 1937, č. 218, s. 3.

94 Pražské noviny, 18. 9. 1937, č. 219, s. 3.

95 Skrăbta za pokojnija Masarik. Pomeni i traurni tăržestva v Sofia. Slovo, 18. 9. 1937, č. 4563, s. 3.

96 Pogrebenieto na Masarik. Dnešnata služba v katoličeskata cărkva. Slovo, 21. 9. 1937, č. 4565 s. 3.

97 Našinec, 23. 9. 1937, č. 217, s. 2. 
du mužský pěvecký sbor „Gusla“ zazpíval bulharskou hymnu, hymnu bulharského cara a československou hymnu. Ve velkém sále bulharské akademie věd byli přítomni přední představitelé bulharského politického a intelektuálního života - předseda bulharské vlády G. Kjoseivanov, bulharští ministři a generálové, předseda bulharské akademie věd prof. Bogdan Filov, rektor sofijské univerzity a z diplomatického světa československý, sovětský, turecký, polský, italský vyslanec, představitelé jugoslávského, rumunského, anglického, francouzského, amerického a řeckého vyslanectví a holandský konzul. ${ }^{98}$ Předseda Bulharsko-československé vzájemnosti dr. Boris Jocov promluvil o Masarykových zásluhách na uskutečnění národních ideálů Československa. Československý vyslanec Prokop Maxa srovnával Masarykův význam pro československý národ s významem svatého Václava, Jana Husa, Jana Amose Komenského, Františka Palackého. Slavnost byla zakončena státními hymnami. ${ }^{99}$

Na pohřbu zesnulého Masaryka bulharský panovník v Praze být nemohl. V popředí jeho zájmu bylo v této době projednání nového volebního zákona, jehož přípravy se aktivně zúčastnil. Podle záznamu československého vyslanectví v Sofii car Boris III. plánoval po přijetí zákona nastoupit cestu do Francie a Anglie a „snad na zpátečni cestě se chtěl „zastavit v Praze a položit osobně věnec na hrob prezidenta-Osvoboditele v Lánech“. Protože se bulharský panovník zdržel v Londýně déle, k takové návštěvě nedošlo. ${ }^{100}$

Zpráva o smrti T. G. Masaryka pronikla do českých a slovenských osad v severním Bulharsku (Vojvodova, Mrtvice, Gorne Mitropolji) až o několik dní později a vyvolala mezi členy české a slovenské kolonie hluboký smutek. Na budovách „Československého národního domu T. G. Masaryka“ ve Vojvodovu, v Mrtvici a v Gorne Mitropolji byly vyvěšeny smuteční vlajky. Každý večer se čeští a slovenští osadníci shromaždovali a s velkým zájmem sledovali v československých a bulharských časopisech zprávy o národním smutku v Československu. Na smuteční slavnosti ve Vojvodovu promluvili o prezidentu Masarykovi správce místní československé školy, místní starosta a zástupci místních náboženských spolků, byly přečteny modlitby a soustrastný dopis, který místní Češi zaslali československému prezidentu E. Benešovi: „Neskonale zavázáni nesmrtelnému prezidentu-Osvoboditeli, jehož drahé jméno nese náš Národni dům a jehož jménem jsme ožili, žijeme a jehož jménem budeme žit $i v$ našich dětech, prosime, abyste přijal naši hlubokou a upřimnou soustrast." $\mathrm{V}$ den pohřbu prezidenta Masaryka zněly od začátku pohřbu kostelní zvony v českých a slovenských osadách v Bulharsku půl hodiny. ${ }^{101}$ Po Masarykově smrti tedy budovy Československého národního domu T. G. Masaryka už přebíraly pro „bulharské Čechy a Slováky“ úlohu „místa paměti“ (Lieux de mémoire).

98 „Žalejno săbranie za Masarik“. Mir, 22. 9. 1937, č. 11150, s. 2; „Car Boris při smutečni slavnosti“. Pražské noviny, 23. 9. 1937, č. 224, s. 3.

99 „Žalejno săbranie za Masarik“. Mir, 22. 9. 1937, č. 11151, s. 2.

100 AUTGM, f. EB, odd. I, sign. R 289, Bulharsko 1935-1938, kart. 149, sl. 687.

101 „Smutek naších krajanů v Bulharsku“. Pražské noviny, 24. 9. 1937, č. 225, s. 2. 


\section{Bulharský obraz zesnulého Masaryka v kontextu bulharských, česko- slovenských a evropských moderních dějin}

Bulharský tisk nevěnoval T. G. Masarykovi pouze kondolenční články a jeho obšírné životopisy, ale hodnotil také jeho význam pro Slovanstvo a pro vznik Československa. První československý prezident byl srovnáván se zesnulými bulharskými a českými intelektuály.

V deníku Mir bývalý vyslanec v Praze B. Vazov srovnával T. G. Masaryka s čínským filozofem Konfuciem a nazval ho „zesnulým obrem myšleni a jednáni". Podobně jako na oslavách v roce 1930 dominoval i nyní jeden základní motiv - spojení osobnosti Masaryka a Československa. Přední bulharský politik a publicista představil Československou republiku jako Masarykovo dílo: „Masarykovo Československo je jeden kulturni stát.“ Československo představuje důkaz, že různé národy mohou žít společně, uvedl B. Vazov. Nejvíce k tomu přispěl T. G. Masaryk. Československá republika je proto jediným státem ve střední Evropě, v niž funguje demokratická vláda. I po své smrti „Masaryk pořád bude žit, udržovat duch svého národa a ukazovat budouci generaci správnou cestu ve veřejném a politickém životě“, byly závěrečná slova bulharského publicisty. ${ }^{102}$

Podobně jako B. Vazov v Miru i bulharský novinář T. Kožucharov vytvořil obraz československého národa na základě postavy zesnulého prezidenta. Nazýval „Čechoslováky“ vysoce kulturním slovanským národem, který si udržoval silné národní povědomí a vždycky byl předvojem slovanství. Právě pokrokové síly československého národa mu pomáhaly bránit se statečně proti agresi německé kultury. Meziválečné Československo bylo charakterizováno jako „nejbohatší a nejlépe organizovaný stát“, „světlonoš světové civilizace“. ${ }^{103}$ Ve své publikaci T. Kožucharov zároveň opakoval motiv, který dominoval $\mathrm{u}$ bulharských intelektuálů a politiků při jejich hodnocení Masarykovy činnosti v meziválečném období - spojení Masarykova obrazu s Československem: „Masarykův život lze považovat za skutečnou personifikaci československých dějin během poslednich 50 let. "104 Tento motiv byl i důsledkem skutečnosti, že v meziválečném období byl T. G. Masaryk často nazýván „otcem Československa“. „V roce 1919 Masarykova autorita a jeho široké mezinárodni kontakty měly rozhodujici význam při vytvořeni a vybudováni nové slovanské republiky“, uvedl bulharský novinář. Závěrem T. Kožucharov napsal: „Na počest Tomáše Masaryka bude vyvěšna spousta smutečnich vlajek $i$ za hranicemi jeho vlasti, protože nebyl pouze velikým Čechoslovákem, ale i velikým občanem lidství, moudrým mužem, zvoleným Prozřetelností byt vưdcem svého národa. Tedy $i$ my, Bulhaři, spolu s ostatními kulturními národy vyjádř́me náš smutek nad drahou a obrovskou ztrátou bratrského československého národa." 105

V novinách Slovo bulharský novinář Jordan Mečkarov popsal zesnulého Masaryka jako soubor několika postav z české minulosti: „V osobnosti Masaryka Češi vidí lásku Jana Husa $k$ pravdě, hrdinskou statečnosti [Jana] Žižky, otcovskou laskavost [Petra] Chelčického, neobyčejnou pili [Jana Amose] Komenského, úsili [Josefa] Dobrovského, ostré pero [Karla] Havlícka

102 Vazov, Boris: Mir, 15. 9. 1937, č. 11144, s. 1.

103 Kožucharov, Todor: Tomaš Masarik. Slovo, 15. 9. 1937, č. 4560, s. 1.

104 Tamtéž.

105 Tamtéž. 
[Borovského] $i$ široký intelektuální rozhled [Františka] Palackého, které symbolizovaly minulost a prítomnost českého národa." První československý prezident byl dále popsán jako dokonalý člověk a byl zbožňován: „Domnivaám se, že Československo je jediným státem na světě, v němž jeho prezident je tak silně obdivován. “ „Pokud dnes bude provádèn plebiscit o vyhlášeni Masaryka za svatého, v celém státu bezpochyby veškeré obyvatelstvo by to podpořilo jako něco naprosto přirozeného. "106 T. G. Masaryk byl tedy nejen ztotožňován s moderními českými dějinami, ale i jeho postava byla zbožňována.

Masarykova smrt měla v bulharském slavjanofilském periodickém tisku velký ohlas. V př́loze časopisu Slavjanski glas byla uveřejněna chronologie Masarykova života. ${ }^{107}$ Osobnost prvního československého prezidenta hodnotili v slavjanofilském časopisu Slavjanski vesti bulharští intelektuálové a slavjanofilové bratři Stefan (1853-1940) a Nikola Bobčevovi (1863-1938). V úvodníku S. Bobčev nazval zesnulého T. G. Masaryka „otcem“ a „osvoboditelem českého národa“. Bývalý československý prezident byl prezentován jako Mesiáš „předurčený Boží Prožretelností $\mathrm{k}$ mimořádně velkým věcem“ a byl srovnáván s protagonisty anglického filozofa a historika Thomase Carlyle, popsanými v jeho díle „On Heroes [Hero Worship, and the Heroic in History]“. S. Bobčev dále uvedl, že T. G. Masaryk v sobě zahrnoval několik osobností - českého učence, filozofa, profesora, sociologa, historika, československého státníka. $\mathrm{V}$ neposlední řadě byl bývalý československý prezident popsán skrze základní ideologie časopisu (slavjanofilství), tj. jako znalec slovanské problematiky a první lektor slovanských studií v Slavonic and East European School v Londýně během první světové války. Přední bulharský slavjanofil S. Bobčev konstruoval Masarykův obraz z perspektivy koncepce slovanské vzájemnosti a nastínil shody a rozdíly mezi Masarykovým a Kramářovým slovanstvím. ${ }^{108}$

Mladší bratr St. Bobčeva Nikola Bobčev popsal „předválečného“ a „válečného“ Masaryka. V souvislosti s Masarykovou předválečnou vědeckou a politickou činností, bulharský intelektuál kladl důraz na jeho dílo Rusko a Europa, na jeho kontakty s ruskými intelektuály, na jeho úlohu v záhřebském procesu a na jeho pokusy zprostředkovat jednání jednak mezi Vídní a Bělehradem, jednak mezi Bulhary a Srby v předvečer první světové války. Masarykovo životní dílo - vznik nezávislého Československa, hodnotil N. Bobčev jako obrovský př́nos: „Dlouhá léta [před světovou válkou] Masaryk připravoval boj za osvobozeni českého a slovenského národa“. Bulharský slavjanofil popsal Masarykovu zahraniční činnost a jeho spolupráci s Edvardem Benešem a tvrdil, že T. G. Masaryk přesvědčil vlády Dohody, aby podpořily rozpad Rakousko-Uherska. ${ }^{109}$

106 Mečkarov, Jordan:, Kăm večnostta. Slovo, 20. 9. 1937, č. 4564, s. 1.

107 „Deloto na Masarik predstaveno prez naj-značitelnite dati ot života mu“. Slavjanski kalendar za 1938 godina, s. 62-67.

108 Podle St. Bobčeva T. G. Masaryk nepopíral základní principy novoslavismu - vzájemné poznání a respekt slovanských národů. I když T. G. Masaryk a K. Kramář věřili v možné slovanské kulturní a hospodářské sblížení, aplikovali různé metody k dosažení tohoto cíle, tvrdil autor. Srov. Bobčev, S. S.: Tomaš Masarik. Slavjanski vesti, 1. 10. 1937, č. 19, s. 1-2.

109 Bobčev, Nik[ola]: Edin velik dăržaunik i učitel - T. G. Masarik (1850-1937). Slavjanski vesti, 1. 10. 1937, č. 19 , s. $6-8$. 
Redakce časopisů Slavjanski glas a Slavjanska beseda poskytly cizím intelektuálům možnost vyjádřit svoji úctu k zesnulému Masarykovi. V př́iloze časopisu Slavjanski glas byl uveřejněn článek polského časopisu Ruch slowianski věnovaný Masarykově smrti. Autor publikace se zmínil o smutné a depresivní atmosféře v Praze během pohřebního průvodu. Poláci nazvali prvního československého prezidenta „jedním z nás“, tj. považovali ho především za Slovana: „Ve velké slovanské rodině neexistuje národ, který by dosud nedostal od Masaryka bud' přmou, nebo nepřimou podporu“", byla závěrečná autorova slova. ${ }^{110}$

V časopise Slavjanská beseda představil tehdejší československý vyslanec v Bulharsku Prokop Maxa československý národ jako „zvláštni“ a „mesiášsky“" skrze postavu zesnulého prezidenta: „Kvưli své zemépisné poloze v srdci Evropy a během osudových okamžikù československý národ vždycky ,vytvářel' velké osobnosti - svatého Václava, Jana Husa, Jana Amose Komenského."111 V podstatě to znamenalo, že P. Maxa vnesl mesianistické prvky do československých dějin. ${ }^{112}$ Popsal T. G. Masaryka jako Mesiáše: první světová válka udělala z něj vůdce, který „ukončil třistaletý boj za svobodu Čechü“, „obnovil jejich státni nezávislost“ a „sjednotil dvĕ vĕtve národa - Čechy a Slováky, do jednotného státního celku."113

Příspěvek ruského politika a intelektuála Pavla Miljukova byl především vzpomínkový, protože v něm navazoval na své osobní kontakty s T. G. Masarykem v 20. letech. Uvedl, že v této době Československá republika fungovala jako „dobře promazaný stroj“: „V roce 1923, když začaly naše rozhovory, nejdůležitějši otázky - nastoleni nového státního útvaru a administrace byly už vyřešeny. Pracoviště zahranični politiky se nacházelo ve vedlejši místnosti. Tam byla kancelár̆ ministra zahraničních věci E. Beně̌e, který často s prezidentem o událostech diskutoval." V této souvislosti P. Miljukov tvrdil, že první československý prezident již ve 20. letech naznačil možnou kandidaturu Edvarda Beneše jako příštího prezidenta republiky. Ruský politik a intelektuál zároveň popsal své osobní jednání s T. G. Masarykem v 20. letech. Tvrdil, že jako prezident Masaryk svou povahu a chování nezměnil. Podle P. Miljukova T. G. Masaryk s ním projednával dva důležité problémy - 1) překonání mezistranických konfliktů a provádění flexibilní politiky vůči národnostním menšinám žijících v Československu, 2) poměry v Sovětském Rusku. ${ }^{114}$

K všeobecnému smutku se připojily i bulharské nacionalistické vrstvy. Nacionalistická organizace „Otec Paisii“ založená v roce 1927 představovala vlivné intelektuální, ideologické a propagační středisko bulharského vlastenectví a nacionalismu, které usilovalo o plnou revizi poválečných mírových smluv a o zachránění národnostních a kulturních práv bulharského obyvatelstva, které žilo na území sousedních států (Jugoslávie, Rumunska a Řecka). Do popředí své ideologie organizace vytyčila nejen menšinovou otázku, ný-

110 „Slavjanite pred smărtnite ostanki na Tomaš Masarik“. Slavjanski kalendar za 1938 godina, s. 60-61.

111 Maxa, Prokop: T. G. Masarik i čehoslovaškijat národ. Slavjanská beseda, 1937, č. 4, s. 157-160.

112 Prokop Maxa psal z hlediska oficiální ideologie meziválečného Československa. Mluvil o existenci československého národa v 17. století, a dokonce nazýval Jana Amose Komenského „pruním československým emigrantem".

113 Maxa, P.: T. G. Masarik i čehoslovaškijat národ. Slavjanská beseda, 1937, č. 4, s. 157-160.

114 Miljukov, Pavel: Sreštite mi s Masaryk i negovite vyzgledi. Slavjanska beseda, 1937, s. 161-165. 
brž i úlohu intelektuálních elit, silných postav a vůdců. ${ }^{115}$ „Otec Paisij“ věnovala ve svém časopise zesnulému Masarykovi dva články. Ve své publikaci bulharský novinář Georgi Konstantinov (1902-1970) popsal prvního československého prezidenta jako „velikého národního vưdce a státnika“, „obránce demokratických myšlenek a bratrstvi mezi národy“, který „má originální pohled na svět" a slouží jako model k následování pro československou inteligenci. T. G. Masaryk vychovával svůj národ, uvedl dále autor, v duchu „zdravého a kulturního vlastenectvi“, tolerance „k cizim národnostním skupinám v Československu“. Zesnulý prezident-Osvoboditel byl rovněž charakterizován jako stoupenec lidských práv a humanista: „Masaryk šíril koncepce humanismu a nacionalismu“, tvrdil autor. ${ }^{116} \mathrm{Z}$ analýzy je zřejmé, že přední bulharský novinář hodnotil prvního československého prezidenta v souladu s ideologií organizace „Otec Paisij“, a dokonce užíval politický jazyk a frazeologie jejich představitelů.

Bulharský historik a publicista Nikola Stanev (1862-1949) přiblížil Masarykův život v kontextu českého politického života XIX. a počátku XX. století. Představil bývalého prezidenta jako intelektuálního politika a následovníka politických myšlenek Pavla Šafaříka a Františka Palackého, hodnotil Masarykův kritický postoj k slovanské politice Rakouska-Uherska. N. Stanev zároveň srovnával Masarykův a Kramářův Weltanschauung a nastínil jejich rozdílný pohled na myšlenku mezislovanské spolupráce. Když hodnotil Masarykův protirakouský odboj během první světové války, bulharský historik uvedl zajímavý a málo známý fakt o česko-bulharských vztazích - československé jednotky, které založil v Rusku, bojovaly proti Bulharsku na rumunské frontě. Závěrem N. Stanev charakterizoval období Masarykova životního příběhu obdobím silných politických postav. V této souvislosti stavěl zesnulého prvního československého prezidenta do protikladu k ostatním evropským státníkům a vůdcům - s Otto von Bismarckem, hrabětem Camillem Cavourem, Nikolou Pašićem, Józefem Piłsudským, Adolfem Hitlerem, Benitem Mussolinim a s dalšími. T. G. Masaryk se odlišoval od všech ostatních politických vůdců tím, že byl demokratem, nikoli diktátorem, a že vždycky prováděl tolerantní politiku vůči národnostním menšinám Československa. ${ }^{117}$ Lze tedy shrnout, že i v článku N. Stanova byla nastíněna koncepce moderního politického vůdce.

Pražský spolek „Československo-bulharská vzájemnost“ hodnotil Masarykovou osobnost v kontextu bulharských dějin. Na stránkách svého časopisu srovnával jeho protirakouskou činnost v „proním československém odboji“ s aktivitami bulharského romantického básníka a revolucionáře Christa Boteva (1848-1876): „Masaryk je náš Botev“. Oba byli revolucionáři, oba věřili, že „svoboda může býti získána jen zbraní“, oba v zahraničí připravili a zahájili svou politickou a vojenskou činnost. V úvodníku byl Masaryk představen jako stoupenec bulharských národních zájmů - autor článku navazoval na Masarykův názor o národnostním charakteru Makedonie a na jeho mnichovské přednášky

115 Poppetrov, Nikolaj: Bălgarskijat nacionalem văpros v interpretaciite na syiuzite „Otec Paisij“ (1927-19301941/1943), In: 100 godini ot Ilindensko-Preobraženskoto văstanie. Sbornik dokladi ot meždunarodna naučna konferencija v Sofia, 26-27 septemvri 2003, Sofia 2005, s. 523-543.

116 G. K. [= Georgi Konstantinov]: Evropa izgubi edin goljam dăržavnik i filosof. Otec Paisij, septemvri 1937, č. 7, s. $277-278$.

117 Stanev, N[ikola]: Tomaš Masarik kato dăržavnik. Otec Paisij, oktomvri 1937, č. 8, s. 296-301. 
v únoru 1914, kde mluvil se sympatiemi o poraženém Bulharsku po druhé balkánské válce. Na závěr redakce časopisu zdůraznila Masarykovo duchovní dědictví: „Masarykova jména se často dovolávají ti, kteří bojují proti dnešnímu politickému nebo sociálnímu systému ve své zemi. Tu je třeba si připomenout, že Masaryk je duch pozitivní, vyžaduje ohled, takt, žádá práci a diskuzi. Proto ti, kteří se ho chtějí dovolávat, mají povinnost domyslit Masaryka až do konce." 118

V Národnich listech připomněl český novinář Vladimír Sís, jeden z členů „Československo-bulharské vzájemnosti“, své jednání s prvním československým prezidentem v lednu 1919 v Praze a představil ho jednak jako bulharofila, jednak jako „revolucionáře“. Podle Vl. Síse tehdejší československý prezident projevoval zájem o poválečnou situaci, v níž se Bulhaři nacházeli, a vyjádřil jim svoje sympatie: „O bulharském národě se [T. G. Masaryk - pozn. aut.] vyslovil velmi pochvalně, chválil jeho pracovitost, trpělivost, houževnatost a střizlivost. “119 V článku dále Vl. Sís tvrdil, že jednání se týkalo i prvního českého odboje a že T. G. Masaryk navazoval na shodu dvou memorand, které oba napsali v zahraničí: ,Jedno memorandum mluvilo pro vnitřni odboj, druhé pro zahranični, nevědèli jsme o sobě, ale chtèli jsme jedno a společným úsilím také jednoho dosáhli: svobody!"“20 Můžeme tedy konstatovat, že podobně jako bulharští politikové a intelektuálové v 20. letech také Vl. Sís se v tomto př́padě přikláněl $\mathrm{k}$ Masarykovu politickému táboru a demonstroval totožnost mezi svou a Masarykovou ideologií, na níž byl československý stát založen.

\section{Bulharské reflexe Masaryka a Československa v roce 1938}

Smuteční slavnosti na počest zesnulého prvního československého prezidenta pokračovaly počátkem následujícího roku. V únoru roku 1938 byly za účasti československého vyslance v Bulharsku uspořádány přednášky věnované Československu. Tyto přednášky P. Maxa označil za „vzpomínku na prezidenta-Osvoboditelé“, což vyvolalo bouři potlesku. Československý vyslanec dodal, že bulharské sympatie k Československu jsou živé kvưli jeho demokratickému zř́zení. ${ }^{121} \mathrm{O}$ životě a díle T. G. Masaryka přednášel v přeplněném sále Slovanské besedy předseda bulharsko-československé vzájemnosti v Sofii univerzitní profesor B. Jocov. Po přednášce byl promítán film „Poslední léto a poslední cesta prezidenta Osvoboditele“. ${ }^{122} \mathrm{O}$ měsíc později zahájil Československý národní dům „T. G. Masaryka“ svoji valnou hromadu pietní vzpomínkou na prvního československého prezidenta. Byly odeslány pozdravy prezidentu republiky E Benešovi, ministerskému

118 „Masarykouské glosy“. Československo-bulharská vzájemnost, listopad 1937, č. 3, s. 1.

119 Sís, Vladimír: T. G. Masaryk o Bulharsku. Národní listy, 19. 9. 1937.

120 Tamtéž. Je možné předpokládat, že tuto část jednání Vl. Sís popsal v souvislosti s vydanou knížkou M. Paulové o dějinách Mafie v témž roce (1937), v nichž autorka detailně nastínila shody a rozdíly mezi Masarykovým a Sísovým memorandy. Srov. Paulová, Milada: Dějiny Maffie. Odboj Čechů a Jihoslovanů za světové války 1914-1918. Díl 1. Praha 1937, s. 407-415.

121 NA v Praze, f. MŠANO, kart. 3548, č. j. 31054.

122 „Kulturni zprávy“. Slovanský přehled, 18. 6. 1938, č. 6, s. 274-275. 
předsedovi M. Hodžovi, ministru Kroftovi a dalším. ${ }^{123} \mathrm{~V}$ dubnu a květnu „Bulharsko-československá vzájemnost“ uspořádala tři zájezdy do bulharských měst Vratce, Peštery a Dupnici, kde se promítal film o T. G. Masarykovi. O zesnulém prvním prezidentu promluvil lektor češtiny na Univerzitě v Sofii K. Hora. ${ }^{124}$

Bulharská společnost nejen vyjadřovala svůj smutek nad zesnulým T. G. Masarykem a jeho politickým dědictvím, nýbrž část z ní demonstrovala i svůj negativní postoj k německým územním požadavkům vůči Československu v roce 1938. Na jaře roku 1938 na schůzi svého spolku „Bulharská Sedjanka“ bulharští studenti v Praze zaslali prezidentu Československé republiky E. Benešovi dopis, v němž vyjádřili svoji víru v morální a mravní schopnosti československého národa „bránit mír a klid na tomto nejcitlivějším místě nejen Evropy, ale i celého světa“: „Národ Husa, Komenského, demokrata krále Jiřriho z Poděbrad, jednookého vůdce Žižky, národ Masarykův, národ, který stojí již tolik století jako přední stráž celého Slovanstva, vždy najde v sobě dostatek mravních sil, aby s klidem a odvahou šel vstříc každému bouřlivému dění." ${ }^{25}$ Mnoho bulharských studentů studujících v Československu se aktivně zúčastnilo v protestních demonstrací před budovami britského a francouzského vyslanectví v Praze. Bulharští studenti se obrátili na sovětského vyslance s prosbou, aby zprostředkoval pomoc Sovětského svazu na obranu Československa. ${ }^{126}$ Zároveň se hlásili k přijetí do československé armády, byli ale odmítnuti, protože nebyli československými občany. ${ }^{127}$

Je známo, že zesílený britský a francouzský nátlak na Československo přinutil Beneše odstoupit Německu česká pohraniční území. Oficiální bulharské stanovisko se nelišilo od postoje velmocí. Koncem září roku 1938 po svém rozhovoru s Hitlerem bulharský car Boris III „doporučil“, aby v „zájmu zachování míru“ Československo odstoupilo tato území Německu. ${ }^{128}$ Bulharská vláda podpořila Mnichovskou dohodu, protože v ní viděla možnost na revizi mírových smluv a připojení bulharských zemí, které ztratilo po první světové válce. Bulharské vládní kruhy zároveň demonstrovaly před československým vyslancem v Sofii Prokopem Maxou svou slovanskou solidaritu a dokonce vyjádřily znepokojení z budoucnosti slovanských států a evropského míru. ${ }^{129}$ Bulharský tisk prosazoval politiku bulharské vlády. Přestože v meziválečném období vysoce hodnotil Masarykovu osobnost a charakterizoval Československo jako moderní a demokratický stát, který

123 NA v Praze, f. MŠANO, kart. 3548, č. j. 43559/38.

124 „Kulturni zprávy“. Slovanský přehled, 18. 6. 1938, č. 6, s. 274-275.

125 „Bulharští studenty pro naši republiku. Krásný projev bulharsko-československého přátelstvi“. Národní politika, 29. 5. 1938, č. 147, s. 14.

126 Centrralen dăržaven archiv, fond $2083 \kappa$, opis 1, a.j. 54.

127 Kolářová, Marie: Organizace pokrokových bulharských studentů v Praze v letech 1918-1938. Slovanský přehled, 1987, č. 3, s. 241.

128 Rychlík, J. - Penčev, V. - Kouba, M.: Česko-bulharské vztahy. In: L. Hladký a kol., Vztahy Čechů s národy a zeměmi Jihovýchodní Evropy, s. 239.

129 Kočankov, Nikolaj: Bălgarija i Slovakija (1938-1944): politika i diplomacija v evropejskija jugoiztok. Sofija 2017, s. 102-103. Za zmínku stojí i skutečnost, že českoslovenští spojenci v Malé Dohodě Rumunsko a Jugoslávie nejen odmítli svou podporu československé vládě v otázce německých nároků na Sudety, ale již v květnu 1938 na mezispojenecké schůzi v Rumunsku doporučili Československu, aby vyhovělo německým požadavkům. Srov.: Tamtéž, s. 54-55. 
prováděl tolerantní politiku vůči svým menšinám, na podzim roku 1938 podpořil Mnichovskou dohodu, protože se domníval, že umožnila řešení jednoho z teritoriálních problémů ve Střední Evropě..$^{130}$

Postoj bulharské vlády a bulharských novin lze vysvětlit několika okolnostmi. Navzdory tradičnímu československo-bulharskému přátelství, Bulharsko se v konkrétním př́ípadě řídilo svými vlastními zahraničněpolitickými zájmy. Bulharský postoj lze vysvětlit i dalšími okolnostmi - na rozdíl od 20. let, v druhé polovině 30 . let Bulharsko už nepotřebovalo tak naléhavě československé zprostředkování k vyrovnání s Jugoslávií. Počátkem roku 1937 Bulharsko a Jugoslávie uzavřely dohodu o „věčném přátelství a pevném míru“, čímž bulharský stát překonal mezinárodní izolaci; navíc v druhé polovině 30. let se Bulharsko více a více přiklánělo $\mathrm{k}$ německému táboru.

Československý vyslanec v Bulharsku P. Maxa ve svých zprávách uvedl, že postoj bulharské společnosti k Mnichovské dohodě nebyl jednotný. Podle něj členové studentské sekce „Bulharsko-československé vzájemnosti“ a členové Jednoty slovanské mládeže (pobočka Slovanského spolku v Sofii), které označil jako „demokratickou mládež“ neskrývali své sympatie k Československu a byli naladěni protiněmecky, zatímco „fašističtí studenti“ (jak je nazval) uspořádali „hlučnou revanšistickou demonstraci“. P. Maxa rovněž sdělil, že se na obranu Československa hlásili i bývalí bulharští studenti, kteří se už vrátili do své staré vlasti, jejich iniciativa byla ale bulharským zákonodárstvím znemožněna. ${ }^{131}$

Faktem je, že reakce bulharských studentů na Mnichovskou dohodu nebyla jednotná. Pravicový BNSS, který v meziválečném období vysoce hodnotil Masarykovu osobnost, se přikláněl k postoji bulharské vlády a zaujal proněmecké stanovisko. ${ }^{132} \mathrm{Na}$ rozdíl od nich levicoví studenti uspořádali protestní demonstrace před německým vyslanectvím a manifestovali před československým vyslanectvím jako projev solidarity s Československem. ${ }^{133}$

V záŕí roku 1938 uspořádaly Československý národní dům T. G. Masaryka ve spolupráci s Bulharsko-československou vzájemností a dalšími organizacemi ve výroční den pohřbu T. G. Masaryka (21. záŕí) v Národním domě v Sofii vzpomínkovou tryznu na pamět prvního výročí skonu a pohřbu bývalého prezidenta. Národní dům v Sofii byl přeplněn Čechy a bulharskými stoupenci Československa. Mezi př́tomnými byli bývalý ministerský předseda Stojan Danev, univerzitní profesoři B. Jocov, Stojan Romanski, Michail Arnaudov, prof. Stefan Badžov, bulharský spisovatel Anton Strašimirov, ředitel carských vědeckých ústavů Ivan Bureš, zástupci kulturních a uměleckých organizací, představitelé bulharského a zahraničního tisku, studenti atd. Smuteční slavnost měla být doprovázena bohatým programem, který měl zahrnovat oficiální projev československého vyslance, literární vystoupení bulharské básnířky D. Gabe a představení českých písní ze stř̌edověku a raného novověku („Svatý Václave“, „Kdož jste boží bojovníci“); úryvky z české opery

130 V listopadu roku 1938 uspořádaly nacionalistické kruhy v Sofii veřejné demonstrace, na nichž usilovaly o revizi mírových smluv. Srov. Tamtéž, s. 102, 107.

131 Izvori za bălgarskata istorija. Díl XIX: Češki i slovaški izvori za bălgarskata istorija. Dí1 4. Sofie: 2008, dok. č. 77, 30. 9. 1938, s. 141-142.

132 Tărnev, D.: Nova Evropa. Studentská borba, 1. 11. 1938, č. 1, s. 5

133 Mitev, Jono: Stávka studenti̊ Sofijské univerzity 16. - 18. března 1939 na obranu Československa. In: Československo-bulharské vztahy v zrcadle staletí. Praha 1957, Sofia. 196. 
„Libuše“. Vyvrcholením večera měla být česká lidová píseň „Ach synku, synku, doma-li jsi...", která byla zpívána na Masarykově pohřbu. ${ }^{134}$

Před zahájením vzpomínkové oslavy došla z Prahy zpráva, že vláda republiky musela přijmout ultimativní návrhy Anglie a Francie o odstoupení pohraničních území státu. „Shromážděni se zmocnilo bolestné vzrušeni. Zatím co ženy se slzami v očích obracely své zraky $k$ poprsi prezidenta-Osvoboditele, $k$ obrazu prezidenta Beneše a státni československé vlajce, muži a členové [české] kolonie projevovali turdé odhodlání, dát své osobni služby $k$ dispozici armádě a ohrožené vlasti“, uvedl v oficiální diplomatické zprávě P. Maxa. Ve svém oficiálním projevu československý vyslanec v Sofii vyjádřil neochvějnou věrnost „celé československé kolonie v Bulharsku prezidentu republiky, vládě, armádě a národu “. Jeho slova byla provázena projevy sympatií a byla „přerušována přitomnými Bulhary několikaminutovými bouřlivými ovacemi Československu, jeho prezidentu a armádě“. ${ }^{135}$ Je zréejmé, že navzdory oficiálnímu postoji bulharské vlády část bulharské veřejnosti vyjádřila s Československem svoji solidaritu. Na druhé straně lze tuto smuteční událost hodnotit nejen jako projev respektu k památce zesnulého T. G. Masaryka a morální podpory československému národa, nýbrž i jako symbolický pohřeb Masarykova „životního díla“ - první Československé republiky.

\section{Závěr}

V meziválečném Bulharsku se stal první československý prezident objektem obdivu a idealizace. Bulharská společnost obracela svoji pozornost k velkým osobnostem a viděla v Masarykovi mesiáše, který bude schopen vyřešit bulharské zahraničněpolitické problémy. Masarykův obraz v meziválečném Bulharsku byl však idealizovaný, nikoli realistický, protože jeho př́nos k překonání mezinárodní izolace Bulharska nebyl velký ani rozhodující. ${ }^{136}$

Mytologizace a sakralizace prvního československého prezidenta dosáhly v Bulharsku svého prvního vrcholu během oslav jeho 80 . narozenin a vyvrcholily znovu při příležitosti jeho smrti v roce 1937. Poslední událost bezpochyby přitahovala pozornost nejen v Československu, ale v celém světě. Bulharsko nezi̊stalo pozadu. K všeobecnému smutku se připojili nejen bulharští státníci, politici a intelektuálové, ale i širší vrstvy bulharské společnosti. Při hodnocení Masarykova života a činnosti v bulharské společnosti dominoval jeden základní motiv - obrazy Československa a jejího prvního prezidenta byly záměrně spojeny. Bulharští intelektuálové a politikové charakterizovali Československou republiku jako Masarykovo dílo a model k následování. Jednotlivé skupiny a intelektuální kruhy v Bulharsku (slavjanofilové a nacionalistické organizace) hodnotily osobnost prvního

134 NA v Praze, f. MŠANO, kart. 3548, č. j. 140656/38.

135 Tamtéž.

136 Detailně k tomu: Hladký, Ladislav: T. G. Masaryk a Jižni Slované. In: Korespondence T. G. Masaryk-Slované: Jižní Slované, s. 37-39; Rychlík, Jan: T. G. Masaryk, Bulhaři a makedonská otázka; Marholeva, K.: Obraz T. G. Masaryka v Bulharsku při př́ležitosti jeho 80. narozenin; Táž: Tomáš Garrigue Masaryk a Bulharsko v obdobi let 1918-1923; Veljanovski, Novica: T. G. Masaryk a makedonská otázka, In: Doubek, Vratislav - Hladký, Ladislav - Vlček, Radomír a kol.: T. G. Masaryk a Slované. Praha 2013, s. 365-372. 
československého prezidenta skrze svou politickou ideologii. Pomocí obrazu T. G. Masaryka bulharští intelektuálové a politikové nastínili svoji koncepci českých/československých dějin. V této souvislosti je pozoruhodné zaznamenat, že v roce 1938 se veřejný smutek po Masarykovi postupně transformoval v solidaritu s první Československou republikou.

\section{T. G. Masaryk's "Second Life" in Bulgaria (1937)}

T. G. Masaryk's prestige in Bulgaria during the 1920s and 1930s was positive and very high. Bulgarian official circles and society were convinced that the first Czechoslovak president would use his authority to support Bulgaria's efforts for overcoming the international isolation and if possible, for revision of the Versailles system of peace treaties. Although these expectations stood on sandy foundations, T. G. Masaryk's reputation among Bulgarians remained high even after his abdication in 1935 .

The death of T. G. Masaryk in 1937 was met with sorrow and grievances by Bulgarian society. The Bulgarians governmental circles Bulgarian periodical press devoted many articles to him. Bulgarian journalists and other representatives of the Bulgarian intelligentsia (especially slavophile-minded intellectuals) assesses the qualities of the first Czechoslovak president as a scholar and as a statesman He was depicted as a "great national leader", "a champion of the democratic ideas and fraternity between nations". Most of publications focused on his contribution to establishing and building up the Czechoslovak state. T. G. Masaryk was characterized as a "father" and "a liberator of the Czech nation". That's why the image of T. G. Masaryk and Czechoslovakia were intentionally united. He was compared to prominent figures of Bulgarian, Czechoslovak and world history.

By irony of fate, the commemmoration of T. G. Masaryk's death in 1938 coincided with the Munich agreement that had a decisive role in the future development of Czechoslovakia. Although Bulgarian government and part of the Bulgarian society supported the Munich agreement, the image of T. G. Masaryk among Bulgarians remained positive. That's why for those Bulgarians, who disagreed with the Munich agreement, commemmoration of the first Czechoslovak president turned into a "symbolic funeral" of the First Czechoslovak republic. 